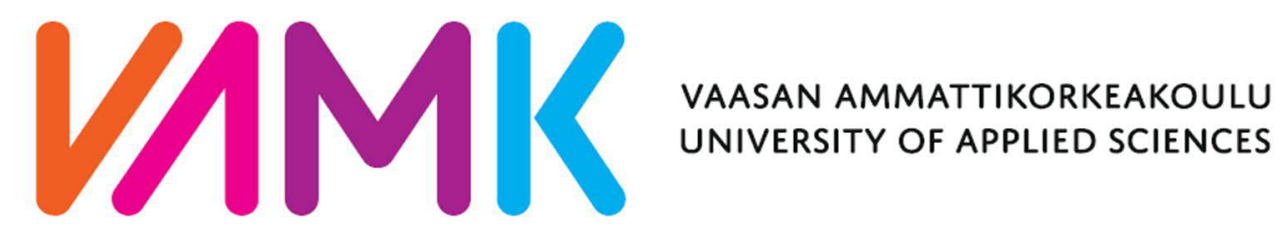

THIS IS AN ELECTRONIC REPRINT OF THE ORIGINAL ARTICLE

Please cite the original article:

Naaranoja, M., Vares, J. 2017. Knowledge Sharing in Constructability Management. In: Uden L., Lu W., Ting $\mathrm{IH}$. (Eds.) Knowledge Management in Organizations. KMO 2017. Communications in Computer and Information Science, vol 731. Springer, Cham, 84-94.

https://doi.org/10.1007/978-3-319-62698-7 8

Version: Final draft

Copyright: (C) 2017, Springer International Publishing AG 


\title{
Knowledge Sharing in Constructability Management
}

\author{
Abstract: The paper studies knowledge sharing related to constructability management in large \\ infrastructure projects. The paper is based on 18 interviews in one MNC company. It analyses the role of \\ knowledge and incentives of knowledge sharing related to constructability.
}

\section{Introduction}

A building design and production process can be defined as a knowledge management process for the actors involved in terms of understanding what the building to be developed is about, and how it should be designed and constructed to respond adequately to the needs of the parties. Knowledge management in the context of a building process means: understanding and learning the design to be made, the usability and constructability of the building, the client's wishes, expectations and needs, user needs, how to deal with the design and its visual impact to the observer and within the context of the build environment. This paper focuses the role of constructability in the building process. Constructability is a practical approach which integrates the design and construction processes, in order to provide a more effective and cost effective solution to a construction project.

Construction projects are often large and complex, thereby the number of professionals involved in projects lengthen the project life cycles and generate complex interfaces (compare Aets et al 2016, Chou et al 2012, Gasik 2011). This in turn influences the types and quantities of project-related information that are generated, making them more fragmented and more complex. Accordingly, development projects require substantial amounts of specific knowledge. Project management capabilities are based on the resources in the project and the capabilities of the project network (Brady and Davies, 2004; and Davies and Brady, 2016). According to Naaranoja and Uden (2007) the most common failure reasons were lack of decision making process, lack of time for planning, difficulty in updating construction regulations, users do not known what they need, lack of trust, lack of risk assessment, resistance to use of IT, and lack of change management. This paper focuses on capabilities related to risk assessment, decision making process and change management by using the concept constructability.

Constructability concepts and principles are taken account during the different phase of the project: conceptual planning, design, procurement and construction, and the improvement of the construction processes generally, and making the process easier to manage, faster and more cost effective. The best possible constructability implementation starts at the very beginning of the project and lasts through the construction and installation, to the maintenance and to the daily operations. While the benefits of the constructability are recognized, there are often barriers to implement constructability optimization in the projects. (Gambatese et al 2007) The design and construction processes in the life cycle of a construction project are many times separated in traditional construction business. The separation of design and construction has caused challenges as the designers are working many times on only on their own field, which might sometimes require costly and complicated sequences and methods to construct at site. It might also happen that the contractor does only what he is told to do, even in a manner that may be inefficient.

The knowledge sharing should not only be understood as a sharing process between individuals like specific designer of the team but as a collective process where all involved actors cooperatively participate. The goal of this paper is to analyse the role of knowledge in using constructability principles in large infrastructure projects in an MNC company. The paper is based on 21 interviews where both project management team and site management members were interviewed. The analysis covered also many other issues but this paper focuses on the role of knowledge that either enables or is a barrier of the using of constructability principals.

\section{Knowledge sharing incentives}

The incentives related to knowledge sharing can be divided to monetary and non-monetary incentives (e.g. Hau et al., 2013). Additionally, it has been shown that sometimes non-monetary incentives have a bigger effect than monetary 
incentives (Kube et al., 2012). Even the strength of explicit economic incentives varies with context (Fehr \& Falk, 2002). Hence, by allowing non-explicit incentives also to exist, the analysis of the collaboration motivation can become realistic Assumption of the employees being rational utility maximizing agents. (Laitinen \& Sanoo 2016)

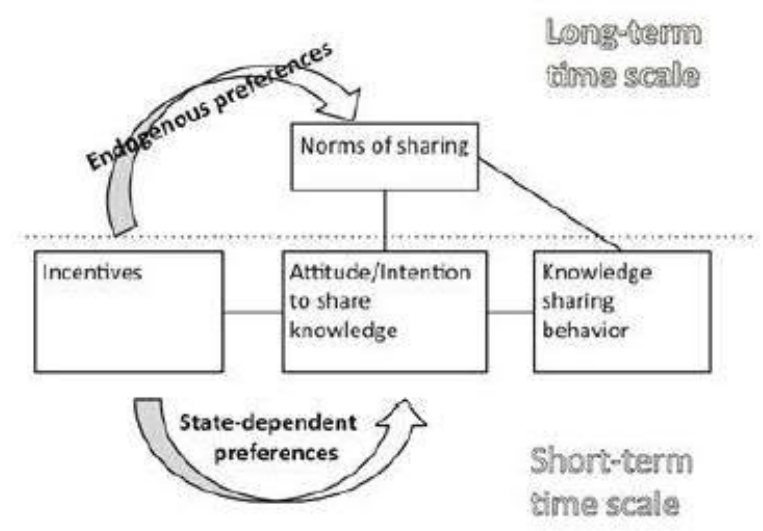

Figure 1. The influence of incentives on knowledge sharing (Laitinen \& Sanoo 2016)

To encourage knowledge sharing incentives can be used. According to Laitinen and Sanoo (2016) there is no consensus on if incentives actually have a positive or a negative effect on sharing levels. The incentives can be divided into a management monitored system level incentive, monetary incentive, and self determined sharing.

\section{Knowledge management in projects}

Knowledge is perceived by most project organisations as a vital organisational resource and source of competitiveness. It is being acknowledged that KM can bring about the much needed innovation and improved business performance in the project based industry (Carillo et al 2000). Knowledge is defined as a dynamic human process of justifying personal belief towards the truth (Nonaka et al 2000). It can also be defined as 'know-why', 'know-how' and 'know-who', or an intangible economic resource from which future resources will be derived (Clarke 2001). Knowledge is built from data, which is first processed into information (i.e. relevant associations and patterns). Information becomes knowledge when it enters the system and when it is validated (collectively or individually) as a valid, relevant and useful piece of knowledge to implement in the system (Blumentritt and Johnston 1999).

Project-creators and project team-members work on a project for only a period and then move on. Individually they learn, but that knowledge/those lessons remain with them, and are not necessarily absorbed by the involved permanent organisation(s). There are many ways how this learning is pursued to be used e.g. in project management office instructions, quality management systems and lessons learned databases but most of the learning is waist however. (Aerts et al 2016)

Table 1. Drivers and barriers to KM in public private partnership projects (Aerts et al 2016)

\begin{tabular}{|l|l|l|}
\hline Drivers & $\begin{array}{l}\text { Increased project complexity } \\
\text { o New types and amounts of } \\
\text { construction-related information } \\
\text { o Fragmentation of knowledge retention } \\
\text { bins } \\
\text { o New forms of infrastructure } \\
\text { procurement }\end{array}$ & $\begin{array}{l}\text { Fostering innovation and continuous } \\
\text { improvement and alliance formation } \\
\text { o Long term commitments } \\
\text { o Reduction of rework } \\
\text { o Repeated interaction } \\
\text { o Limited number of potential bidders }\end{array}$ \\
\hline Barriers & $\begin{array}{l}\text { Construction industry culture } \\
\text { o Slow absorption of new knowledge }\end{array}$ & Employee turnover \\
\hline
\end{tabular}




\begin{tabular}{|l|l|l|}
\hline Market logic & Lack of processes and tools for knowledge \\
o Confidentiality of knowledge & transfer \\
O Uniqueness of knowledge & o Lack of organisation level commitment to \\
O Reliability of knowledge & $\begin{array}{l}\text { knowledge management } \\
\text { o Lack of individual level motivation for } \\
\text { knowledge sharing }\end{array}$ \\
\hline
\end{tabular}

Barthorpe et al. (2000) indicate that: "Levels of innovation in the construction industry compared to other industries have been at best modest. The industry portrays a conservative and at times "laggardly" approach to new ideas, mainly due to its fragmented nature and lack of ability to invest time and money into innovation, research and development" ( Barthorpe et al., 2000).

\section{Constructability}

Constructability as a definition is an abstract term, so direct measuring of the constructability cannot be done, it is always project specific and subjective. Every measurer defines the constructability in a different way, through the experiences and habits. If the constructability as a definition is simplified, it can mean that the goals of the project are accomplished in a way, which is effective and fluent. Construction experience and knowledge are keys to the good constructability. Knowledge and understanding of the construction process, the needed information, for example regarding the materials, labour and necessary equipment to build, and the limitations of and constraints on construction work are essential part of the success.

(Gambatese et al 2007)

Addressing of the constructability to the projects can be undertaken informally or through a formalized process. The nature and format of the constructability process is often dependent of the type of project. Addressing the constructability early in the project enables the opportunities to impact to cost and quality of the project. Constructability programs might come at a cost to the project, but the cost, however, is often outweighed by the possible benefits, such as reduced construction costs, less-rework, shorter construction schedules, improved construction site safety and other positive project outcomes.

(Gambatese et al 2007)

A workable concept of constructability needs to be recognized that there are several factors in the project environment, which have an impact on the design and construction processes, and the link between design and construction and maintenance of the power plant or building. (McGeorge et al 2012)/7/

The principal target of constructability is to produce the best product, producing the best possible use of resources. The decisions, which have a significant impact on the ease of construction, are made in the early stages of the project lifecycle. (McGeorge et al 2012)

The constructability management during different phases of the project contains following viewpoints:

Project phase: conceptual planning

1. Constructability program are made an integral part of the project execution plans

2. Early project planning actively involves construction knowledge and experience in order to create an effective project team

3. Early construction involvement is considered by using alternative contracting strategy

4. The project master schedule is construction sensitive

5. Basic design approaches focuses to use major construction methods

Project phase: design and procurement

6. Site layouts promote efficient construction, maintenance and operation

7. Procurement and design schedules are construction driven

8. Designs are configured to enable efficient construction

9. Design Elements are standardized

10. Construction efficiency is considered in detailed design development 
11. Module/pre assembly designs are prepared to facilitate fabrications, installation and transportation

12. Designs promote construction accessibility of personnel, equipment and material

13. Design facilitate construction under adverse weather conditions

Project phase: field operations

14. Constructability is enhanced when innovative construction methods are utilized. (CII 2007)

Qualitative benefits are either a result from strategic or key execution decisions or based on functional analysis. Both above mentioned categories lead typically to the reduction in engineering, construction cost and schedule duration. Strategic decision are having the largest impact on design and construction costs and on the project schedule. Reduction in engineering can be gained through the use of standardized products and design details. Construction costs can be reduced by using labour in a more efficient way through the prefabrication, preassembly an efficient use of construction materials. Several key factors need to be considered in order to get the needed impact on the construction costs and schedule. Factors include contracting strategy, methods and techniques of construction and sequencing. Measurement of these factors can be obtained by evaluating the impact of these changes between the standard practices. (Russel et al 1994)

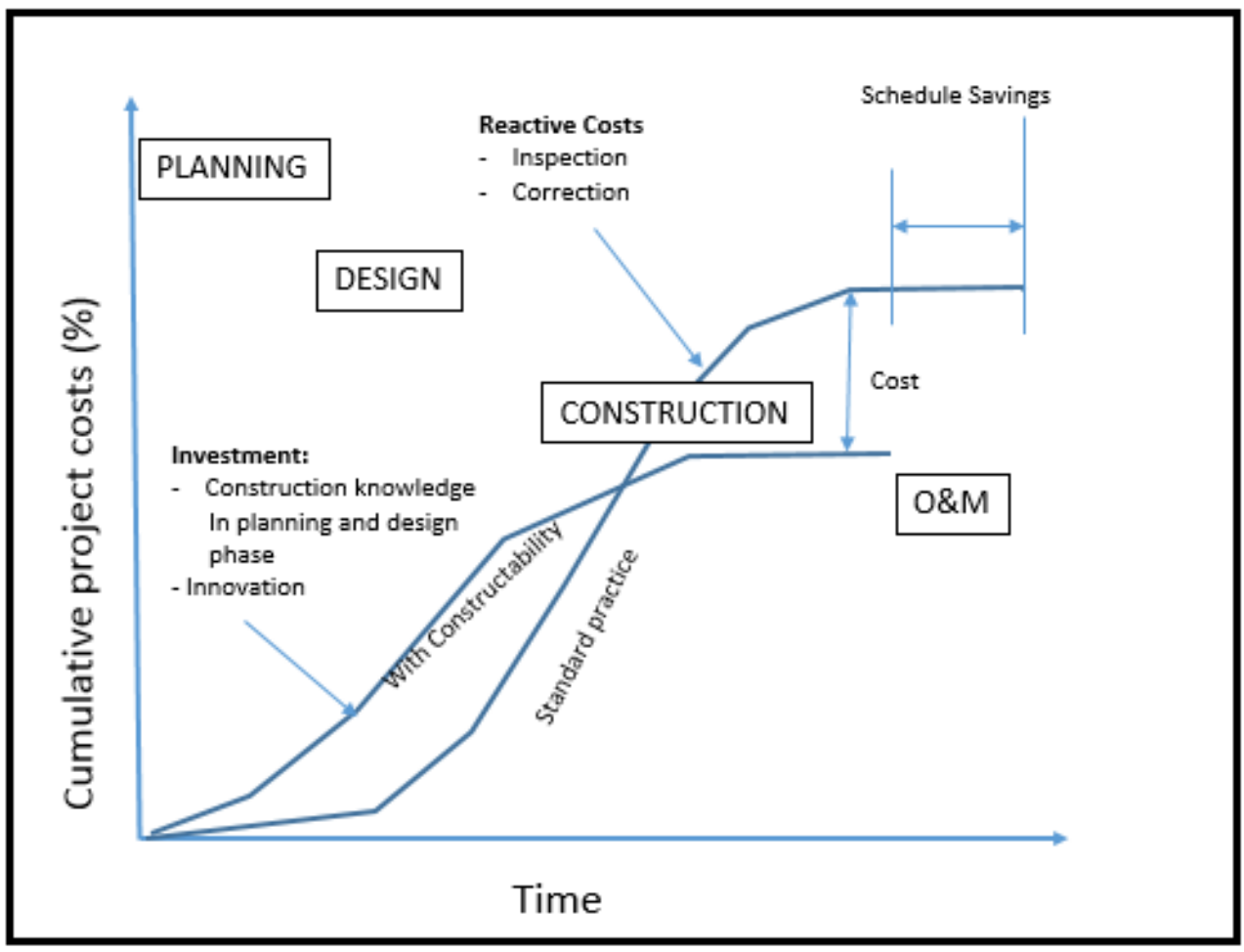

Figure 2. Cost and schedule savings when using constructability principals (Russel et al 1994)

\section{Value Engineering and Constructability}

Value Engineering has been defined as "the systematic effort directed at analysing the functional requirements of systems, equipment, facilities, procedures, and supplies for the purpose of achieving the essential function at the lowest total cost, consistent with meeting needed performance, reliability, quality, maintainability, aesthetics, safety and fire resistance" (Russel et al 1994, O'Connor \& Miller 1994)

Table 2. Comparison of Value Engineering and Constructability (Russel et al 1994) 


\begin{tabular}{|l|l|l|}
\hline Criteria & Value Engineering & Constructability \\
\hline Focus & $\begin{array}{l}\text { Overall reduction of life-cycle } \\
\text { cost }\end{array}$ & $\begin{array}{l}\text { Optimize construction process } \\
\text { in terms of construction cost, } \\
\text { schedule, safety and quality }\end{array}$ \\
\hline Implementation & $\begin{array}{l}\text { A brainstorming session where } \\
\text { life cycle cost alternatives are } \\
\text { considered for systems } \\
\text { components while maintaining } \\
\text { design function }\end{array}$ & $\begin{array}{l}\text { An integral part of project } \\
\text { management and scheduling } \\
\text { allowing construction } \\
\text { knowledge and experience to } \\
\text { be integrated into project } \\
\text { planning and design }\end{array}$ \\
\hline Timing & $\begin{array}{l}\text { Usually performed during } \\
\text { design phase. In many cases } \\
\text { performed as a reactive } \\
\text { process to reduce the cost } \\
\text { after design has been } \\
\text { completed }\end{array}$ & $\begin{array}{l}\text { On-going from conceptual } \\
\text { planning through construction } \\
\text { and start-up }\end{array}$ \\
\hline
\end{tabular}

The implementation of value engineering includes six steps, information, functional analysis, speculation, evaluation, planning/proposal and implementation/follow-up. Value engineering can be done in two ways, either proactively or reactively. The proactive approach includes starting to collect ideas at the beginning of the design, and multiple design options are considered and most cost effective will be chosen. The reactive approach collects cost effective alternatives through the design reviews, it is performed after the design of specific component is complete. The primary objective of value engineering is reduce the total life cycle cost of a facility, whereas constructability focuses on the optimization of the entire construction process. Normally VE is performed during the design phase of the project, and effective constructability program ideally begins during the conceptual planning phase of the project and lasts through the construction. (Russel et al 1994)

Construction optimization and achieving of the lowest life cycle cost can be developed at the same time. VE recognizes the increased benefit from early implementation, however information available during the design and planning phase of the project is normally limited. The implementation of constructability can be as a precursor to $\mathrm{VE}$, by providing information though construction input and lessons learned, that VE could be more effective. (Russel et al 1994)

Total Quality Management, Constructability and Value Engineering are not mutually exclusive. Constructability and Value Engineering are complementary work processes that might be used as key elements in achieving the total quality. (Russel et al 1994)



Figure 3. Constructability and Value Engineering related to the Total Quality Management (Russel et al 1994) 
Fragmented and split scope of the project and unclear roles of the project stakeholders are the significant barriers to implementation and developing of the constructability program successfully. Competitive stance or motivation of construction personnel, obstacles to innovation in design and demarcation of the project are the difficulties and barriers, which create to the further development and use of constructability concepts will not be easy to adapt. (Gambatese et al 2007)

Table 3. Most common constructability implementation barriers (Gambatese et al 2007)

\begin{tabular}{|c|l|}
\hline Rank & \multicolumn{1}{|c|}{ Description } \\
\hline 1 & Complacency with the status quo \\
\hline 2 & Reluctance to invest additional money and effort in early project stages \\
\hline 3 & Limitations of lump sum competitive contracting \\
\hline 4 & Lack of construction experience in design organization \\
\hline 6 & Designer's perception that "we do it" \\
\hline 7 & Construction input is requested too late be value of \\
\hline 8 & Belief that there are no proven benefits of constructability \\
\hline 9 & Owner's lack of awareness/understanding on the concepts of constructability \\
\hline 10 & Misdirected design objectives and designer performance measures \\
\hline 11 & Owner's perception that "we do it" \\
\hline 12 & Lack of genuine commitment to constructability \\
\hline 13 & Designer's lack of awareness/understanding of the concepts of constructability \\
\hline 14 & Poor communication skills of constructors \\
\hline 15 & Lack of documentation and retrieval of "lessons learned" \\
\hline 16 & Lack of team-building or partnering \\
\hline 17 & Poor timeliness of constructor input \\
\hline 18 & The right people were/are not available \\
\hline
\end{tabular}

\section{Research method}

The sampling of the constructability interview was eventually relatively narrow that also has impact on the reliability of the interview results. However, it can be assumed from the interview results that the results indicate the correct direction of constructability level inside the company since the interviewees shared the opinions in general. The amount of interviewees was not added more since no new data was got after 18 interviews. The interviews worked either as project team members and project managers or had the role of site manager and section manager. Unfortunately the interviewees were only from the project team members and did not cover client representatives or other stakeholders but the variety of disciplines was covered like mechanical, electrical and civil.

All the interviews were recorded during the session, and all the results from the interviews were anonymized. The interview focused on the current use and needed use of constructability principals. This paper analyses the knowledge management practice development need related to the use of constructability principals.

\section{Results}

According to the interviews the unconscious and conscious constructability principles are taken into account mainly during the general planning of the project and as a part of project management process. The infrastructure projects in the company have a structured decision making process, but the time for planning is limited, there are difficulties to take into account the local environment so the construction limitations are often not clear, the clients might not be experts in the infrastructure field but the goals are clear for the project group, risk assessment is done as carefully as possible in the time frame, ICT systems are used, and change management procedures are well defined. The constructability was not 
systematically reviewed in the infrastructure projects under one single process, it was buried under other processes such as risk management, project planning and design review.

The constructability process had challenges in non-standard or complex projects and markets. In other words, the use of constructability was not taken into account when the knowledge management of the project was challenging and the lack of specific knowledge prevented the use of constructability principal. The knowledge sharing did not take place due to the lack of knowledge. In other words, knowledge sharing did not happen when there was nothing to share or there was not enough time for sharing and thus the constructability level did not reach to goal.

The case data revealed the willingness for knowledge sharing though the actual sharing did not take place due to lack of time to get knowledge of the complex project. The constructability usage level and quality was seen to be very much linked to the competences and experience of personnel at the company. Thus first step to improve knowledge sharing is to teach or consciously improve the process in order to take more time to learn in the beginning of the project or analyse the constructability.

Improving the use of constructability principles requires not only improving the knowledge of the principals in the system level and individual level but also selecting the experienced knowledgeable staff in complex projects.

The analyses reveals that the complexity of the project prevented the knowledge sharing that should improve the constructability. This is a surprise since normally the complexity requires more knowledge sharing but in this case cosructability management was probably evaluated to be less important than the keeping the timetable of the project though maybe the lacking constructability issue sharing would result more expensive design and construction.

\section{Conclusions}

Knowledge sharing behaviour in constructability management depends partly on the norms of sharing (like risk management, project planning and design review). The attitudes of sharing were weaker when the project was complex and the actual knowledge can be evaluated to be created too late if the personnel was unexperienced. Short term time scale did not find the reason to be the lack of willingness to share but rather the failure to have anything to share.

\section{REFERENCES}

Aerts, G., Dooms, M., \& Haezendonck, E. (2016). Knowledge transfers and project-based learning in large scale infrastructure development projects: an exploratory and comparative ex-post analysis. International Journal of Project Management.

Blumentritt, R. and R. Johnston (1999). Towards a Strategy for Knowledge Management. Technology Analysis and Strategic Management, 11 (3): 287-300

Brady, T and Davies, A (2004) Building project capabilities: From exploratory to exploitative learning. Organization studies, 25(9), 1601-1621.

Carrillo, P. M., Anumba, C. J., \& Kamara, J. M. (2000). Knowledge management strategy for construction: key IT and contextual issues. Proceedings of CIT, 2000, 28-30.

Chou, J.S. Yang J.G., Project management knowledge and effects on construction project outcomes: an empirical study Proj. Manag. J., 43 (5) (2012), pp. 47-67

Clarke, T. (2001) 'The knowledge economy', Education + Training, 43(4/5), pp. 189-196. doi: $10.1108 / 00400910110399184$

Connor JTO (1994) Barriers to Constructability Implementation, Journal of Performance of

Constructed Facilities 8(2), American Society of Civil Engineers

Construction Industry Institute (1987) Constructability Concepts File, Construction Industry Institute, Austin. 
Davies, A, Brady T, (2016). Explicating the dynamics of project capabilities, International Journal of Project Management. 34 (2), pp. 314-327 http://dx.doi.org/10.1016/ j.ijproman.2015.04.006

Gambatese, JA, Pocock, JB, Dunton, PS (2007) Constructability Concepts and Practice. American

Society of Civil Engineers

Gasik S., (2011) A model of project knowledge management, Proj. Manag. J., 42 (3) (2011), pp. 23-44

Laitinen,J, Senoo D (2015) Understanding the Signaling Information of Incentive Programs European Conference on Knowledge Management; Kidmore: 938-944.

Naaranoja, M., \& Uden, L. (2007). Major problems in renovation projects in Finland. Building and environment, 42(2), 852-859.

Nonaka, I., Toyama, R., \& Konno, N. (2000). SECI, Ba and leadership: a unified model of dynamic knowledge creation. Long range planning, 33(1), 5-34.

McGeorge, D., \& Zou, P. X. (2012). Construction management: new directions. John Wiley \& Sons

O'Connor JT., Miller ST (1994) Barriers to Constructability Implementation. Journal of Performance of Constructed 8:2(110) DOI: http://dx.doi.org/10.1061/(ASCE)0887-3828

Russell, J. S., Swiggum KE, Shapiro JM, and Alaydrus, AF (1994): "Constructability related to TQM, value engineering, and cost/benefits." Journal of performance of constructed facilities 8, no. 1 (1994): 31-45. 